\title{
AMERICAN VINES, EUROPEAN POTATOES: AN EVOLUTIONARY HISTORY OF EUROPEAN MIGRATIONS IN SOUTHERN BRAZIL
}

\author{
Rachel Carson Center for Environment and Society \\ Ludwigs-Maximilian University, Munich
}

EDUARDO RELLY

Universidade Vale do Rio dos Sinos UNISINOS

São Leopoldo, Brazil

\section{Abstract}

In this article we examine the migratory history of German and Italian communities in the southernmost Brazilian state of Rio Grande do Sul. In particular, we explore the divergent trajectories of these two communities in terms of agricultural practices, knowledge, environmental adaptation/transfers and agricultural policies. Adopting the critical tools of evolutionary history, we explore these experiences from a perspective that traditional historical analyses have often neglected. While both Germans and Italians were influenced by a cultural heritage from their homelands, non-European plant species such as the Isabella grape and white potatoes played an essential role in the successful migratory effort of these communities, actively interacting with their knowledge and values. In this sense, we argue for the potentially enriching critical perspective posed by an approach to the environmental history of migrations informed by the critical tools of evolutionary history, complementing the anthropocentric narratives produced by this academic field thus far.

Keywords: environmental history of migrations, evolutionary history, Latin American history, wine, grape vines, potato crops

The nineteenth century was an important period for the consolidation of the Brazilian state, just as much as for most countries that emerged from the dissolution of Iberian colonialism. Aside from British Guiana, Brazil was the only monarchy in South America, and it comprised a vast territory traversed by several ecological zones placed mostly within tropical latitudes. Along the borders of the empire, neighbouring countries flexed their muscles, and frontiers in Latin America were anything but fixed. Internally, separatism was an option for many; fuelled by 
the former and fragmented structures of the colonial age, and under the political context of Pedro I's abdication in favour of his young heir Pedro II, regional revolts broke out between 1835 and 1845 in almost every region of the vast tropical empire.

In the southernmost province of the country, Rio Grande do Sul, the Revolução Farroupilha found support in the post-independence geopolitics of the southern cone. The Argentine Confederation exerted influence over the ambitious provincial elites, whose prosperity depended on the success of the cattle ranching economy and military prestige. ${ }^{1}$

Internal and external pressures demanded vigorous action from the court in Rio de Janeiro and, notwithstanding dynastic politics, political struggles among conservatives, moderate and radical liberals, and the respective topic of decentralisation/centralisation, migration emerged as a possible solution to bring stability to the monarchy. ${ }^{2}$ That was exactly the frame for Pedro II's reign (1841-89). Most of the events related in this paper took place in this period.

On the other hand, migration policies in nineteenth-century Brazil cannot be comprehended without a mention of the slavery question. That was not a simple national issue; British pressure over the abolition of slavery-often reputed to be the very base of Brazilian political unity-piled up additional unease among the political class and the elite. ${ }^{3}$ In most parts of the country, European immigrants were destined to sustain the monocultural activities at the core of the Brazilian national economy, mainly coffee plantations situated in the states that were experiencing unprecedented economic growth, becoming the socioeconomic and political centre of the country—such as the states of São Paulo and Minas Gerais. ${ }^{4}$ European settlers were therefore forced to confront working conditions of massive exploitation that became regarded as 'camouflaged slavery' and determined the abrupt termination of migratory flows from Germany and other northern European countries, favouring a massive migratory wave from Italy. ${ }^{5}$ However, in the case of Rio Grande do Sul, the migratory phenomenon became known as colonização (colonisation), as it did not simply consist in importing a labour force from other countries, but in creating new settlements based on small-scale property regimes quite unconventional for a slavery-centred plantation economy such as Brazil's. ${ }^{6}$

1 Luis Augusto Farinatti, Confins meridionais: Famílias de elite e sociedade agrária na Fronteira Sul do Brasil (1825-1865) (Rio de Janeiro: Universidade Federal do Rio de Janeiro, 2007), 397.

2 Emília Viotti da Costa, Da monarquia à república: Momentos decisivos (Sáo Paulo: UNESP, 2007), 14.

Stefan Rinke, Revolutionen in Lateinamerika: Wege in die Unabhängigkeit 1760-1830 (Munich: Beck, 2010), 286.

Beatriz Maria Lazzari, Imigração e ideologia. Reação do Parlamento brasileiro à política de colonização e imigração (Caxias do Sul: UCS, 1980), 15.

5 Emilio Franzina, L'America Gringa. Storie italiane d'immigrazione tra Argentina e Brasile (Reggio Emilia: Diabasis, 2008), 151-3.

6 Caio Prado Júnior, História econômica do Brasil (São Paulo: Brasiliense, 1976), 141. 
In 1824, Germans arrived in Rio Grande do Sul as imported Wehrbauern, replicating military-civil strategies used by the Habsburg and Russian Empires against the Ottomans. ${ }^{7}$ German migration would be a lasting phenomenon for the next several decades, up to the twentieth century. About 50 years later, Italians came and settled on the uplands of the province. Since then, Germans and Italians have shaped the landscapes of the entire region, at times trespassing provincial and even national borders. The colonisation of the Mata Atlântica biome and the establishment of agricultural settlements were then the common ground of both experiences.

Adopting slash-and-burn cultivation, Germans and Italians expanded the agricultural frontiers of the empire according to particular developments. Italians, at least in appearance, resorted to the traditional agricultural practices characterising their homeland, implementing agricultural practices based on vineyards and wheat cultivation. ${ }^{8}$ Conversely, Germans followed local precedents and emphasised native tropical crops, although not exclusively. Both groups of people had to learn a lot from local Brazilian cultivators, who helped them make sense of the new environments they were managing. ${ }^{9}$ Overall, migration, subtropical forests and agriculture formed a hotspot for environmental globalisation in southern Brazil.

In this article, we attempt to reconstruct the divergent trajectories of German and Italian migrations in the southernmost state of Brazil (Rio Grande do Sul), with particular emphasis on the ecological transformations related to this experience. Employing the critical lenses of environmental history, we look at the intermingling of the homeland culture of these two migratory groups with local environmental knowledge and a vibrant foreign territory that presented different ecological characteristics for these groups. We explore these issues by examining two specific crops in the making of these two different groups-respectively, potatoes for the Germans and grape growing for the Italians. Eschewing an anthropocentric approach

7 Gary Marker, 'The Age of Enlightenment 1740-1801', in Russia: A history, ed. G. Freeze (Oxford and New York: Oxford University Press, 2009), 154-5.

8 The idea of 'homeland' is here utilised in a non-literal sense, considering that both Italy and Germany were unified during this migratory experience (respectively in 1861-71 and 1871). Indeed, German immigrants arrived in Southern Brazil during the 1820s, well before German unification, while Italians came a few decades later, although they rarely identified with their homeland but rather with the region and/or the municipality from which they came. However, although the concept of homeland assumes a rather abstract connotation when looking at the trajectory of these groups, common cultural instances and unitary political designs had already been developed in both countries. At the same time, the migratory experience produced a sense of belonging to the motherland in both communities, who started looking at the European lands that they had left as a major cultural reference in order to differentiate themselves from other immigrant communities. For all the reasons above, in this article we have decided to adopt the term 'Germans' and 'Italians' in order to define these communities. For a brief argument on the identity of both German and Italian immigrants, see Olivio Manfroi, A colonizaçäo italiana no Rio Grande do Sul. Implicaçóes econômicas, políticas e culturais [first published 1975] (Porto Alegre: EST Ediçôes, 2001); Sílvio Marcus de Souza Correa, Zur ethnischen identität der deutschstämmigen in Santa Cruz do Sul / Brasilien (Santa Cruz do Sul: Unisc, 2001).

9 Manoel Pereira Rego Teixeira dos Santos, 'O Imigrante e a floresta: Transformaçôes ambientais, das práticas e da produção rural nas colônias do Vale do Itajaí-SC’ (PhD diss., Universidade Federal de Santa Catarina, Florianópolis, 2011), 42 . 
to the migratory history of southern Brazil, we propose a critical view of these migratory processes that stems from evolutionary history and neo-materialism. ${ }^{10}$ If German and Italian settlement experiences were informed by cultural knowledge exported from their homelands, then it would be anticipated that their migratory history was influenced by their encounter with natural species that travelled from other parts of the world and whose biological and genetic characteristics allowed them to thrive in the southern Brazilian environment.

\section{Co-evolutionary migrations}

This study is informed by research documenting the ecological expansion of humankind since the late fifteenth century, as well as by more recent studies assessing the relation between environmental change and migration in several regions of the world between the late nineteenth and early twentieth centuries. ${ }^{11}$ Perhaps more importantly, this article attempts to look at migratory flows in history as organic phenomena in which the dichotomy between natural and social factors disappears, falling into the larger domain of ecological change. ${ }^{12}$ This aim is accomplished by adopting the critical tools provided by evolutionary history and neo-materialism, attempting to address the role of non-human actors in the construction of the ecological niche that these two European groups still occupy to this day. In this sense, following the perspective of environmental history, the successful migratory experience of these European communities in southern Brazil should not be considered only as a colonisation experience aimed at conquering the national ecological frontier and informed by an expansionist political and economic agenda. Rather, this phenomenon should be understood as a co-evolutionary process that led two different human groups from overseas to adapt to an ecosystem that presented several differences from their homelands. This process of encounter created a hybrid landscape in which traditional practices from the cultures of the two countries of origin intermingled with the material characteristics of the local ecosystem.

10 For bibliographical references, see Edmund Russell, Evolutionary History: Uniting History and Biology to Understand Life on Earth (Cambridge: Cambridge University Press, 2011) and Timothy J. LeCain, The Matter of History: How Things Create the Past (Cambridge: Cambridge University Press, 2017), doi.org/10.1017/978131 6460252, respectively.

11 For a general overview on ecological expansion of European people, see William Cronon, Changes in the Land: Indians, Colonists and the Ecology of New England (New York: Hill and Wang, 1983); Alfred Crosby, Ecological Imperialism: The Biological Expansion of Europe, 900-1900 [first published 1993] (Cambridge: Cambridge University Press, 2004), doi.org/10.1017/CBO9780511805554; John F. Richards, The Unending Frontier: An Environmental History of the Early Modern World (Berkeley, CA: University of California Press, 2003). More specifically, for an environmental history of migrations in Brazil, see Eunice S. Nodari and Miguel Mundstock Xavier, 'European Immigration and Changes in the Landscape of Southern Brazil', in Environmental History of Modern Migrations, ed. Marco Armiero and Richard Tucker (London and New York: Routledge, 2017), 41-52, doi.org/10.4324/9781315731100-4.

12 See Armiero and Tucker, Modern Migrations, 5. 
This contested and epistemic process was caused by the concurrence of multiple factors. While the persistence and self-reliance of these communities was essential for the success of this daring enterprise, traditional indigenous knowledge and the unique biodiversity of the region were essential for their survival, especially in the initial stages. However, as Germans and Italians began to establish themselves in the region, they developed agricultural practices that allowed the economy of their colonies to thrive with the establishment of industrial activities based on intensive agricultural production and traditional craftsmanship. ${ }^{13}$ Naturally, this process has determined large-scale environmental transformations, accelerating the destruction of the Atlantic rainforest in favour of the anthropic landscapes that still characterise the region these days.

In this article, we maintain that this process was not only a response to these communities' will to reproduce the circumstances of their homeland. The industrialisation of agriculture in southern Brazil also responded to a political agenda of assimilation promoted by the Brazilian state all over the southern ecological frontier between the late nineteenth and early twentieth centuries, one that transformed these immigrant groups into one of the symbols of the national narrative of ordem e progresso. ${ }^{14}$ Perhaps more importantly, the successful experience of German and Italian immigrants in southern Brazil was facilitated by the characteristics of other biological species that favoured the construction of the ecological niches in which these communities could survive and thrive. Italian immigrants found in wine production a successful enterprise thanks to a foreign plant known as Isabella whose biological characteristics were suitable for local ecologies. Conversely, Germans were able to 're-Americanise' tobacco and potatoesboth crops originally native to the Americas and therefore particularly suitable for the local environment. In southern Brazil, after their introduction from Europe, varieties of 'European' potato were extremely successful in Rio Grande do Sul, while 'Prussian' tobacco successfully reached the fields of the German colonists.

\footnotetext{
13 For further information on the relationship among agriculture, industrialisation and European migration in Rio Grande do Sul, please read Sílvio Marcus de Souza Correa and Juliana Bublitz, Terra de promissão: Uma introdução à eco-história da colonização do Rio Grande do Sul (Santa Cruz do Sul: Edunisc, 2006); Sandra Jatahy Pesavento, RS: Agropecuária colonial e industrialização (Porto Alegre: Mercado Aberto, 1983).

14 On the westward expansion of the Brazilian agrarian frontier, see Claiton Marcio da Silva, 'Modernizar é preciso. Pensamento social e mudança no Brasil rural (1944-1954)', Iberoamericana 15, no. 64 (2017): 195-209. On the continuation of this narrative into the twentieth century, see Sandro Dutra e Silva, 'Nature's Revenge: War on the Wilderness During the Opening of Brazil's Last Western Frontier', International Review of Environmental History 5, no. 1 (2019): 5-21, doi.org/10.22459/IREH.05.01.2019.02.
} 


\section{Migration and environmental adaptation}

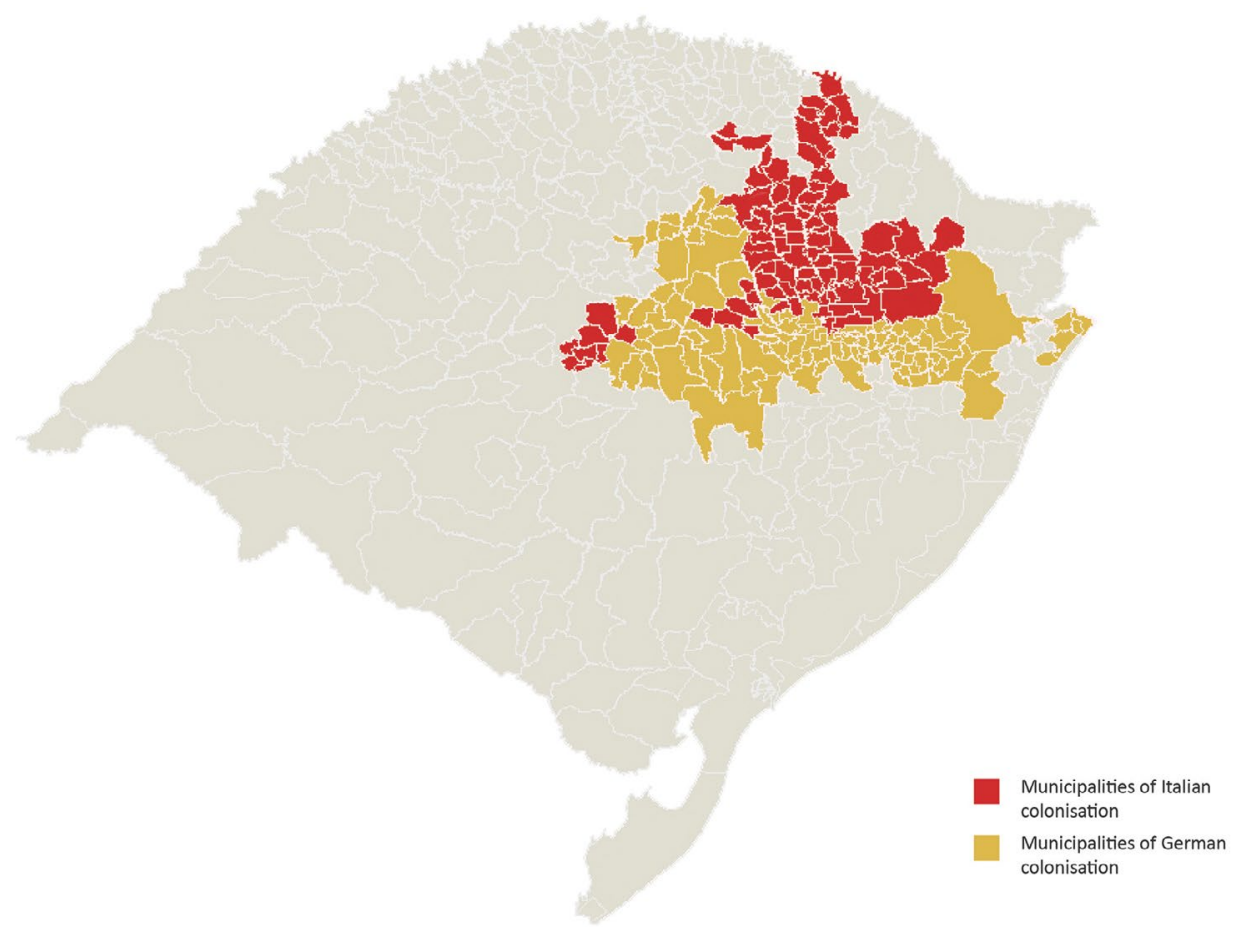

Figure 1: Municipalities of German and Italian colonisation in Rio Grande do Sul. Source: Adapted from Helena Brum Neto, Regiões culturais: a construção de identidades culturais no Rio Grande do Sul e sua manifestação na paisagem gaúcha (Santa Maria: Universidade Federal de Santa Maria, 2007).

\section{Germans}

The foundation of the colony Sáo Leopoldo (1824) marked the beginning of German immigration in Brazil. To be fair, Germans had written since the sixteenth century important pages of Brazilian history through the deeds of people such as Mestre Johan, Hans Staden and Wilhelm Ludwig von Eschwege. ${ }^{15}$ Settlements of German-speaking colonists had been created in 1818 in Nova Friburgo (Rio de Janeiro) and Leopoldina-Frankenthal (Bahia), with disappointing results. ${ }^{16}$ However, none of these previous experiences could match the weight of Sáo Leopoldo for Brazilian-German history. Between 1824 and 1830, 5,000 Germans were shipped

15 Luiz Alberto Moniz-Bandeira, Wachstumsmarkt Brasilien: Der deutsche Wirtschafts- und Handelsbeitrag in Geschichte und Gegenwart (Wiesbaden: Springer Fachmedien, 2013), 2-3, doi.org/10.1007/978-3-658-02202-0.

16 Gisele Sanglard, 'De Nova Friburgo a Fribourg através das letras: a colonização suíça vista pelos próprios imigrantes', História, Ciências, Saúde - Manguinhos 10, no. 1 (2002): 173-202, doi.org/10.1590/S0104-59702 003000100006. 
to Brazil, mostly to São Leopoldo, but also other colonies in Rio Grande do Sul (Três Forquilhas and São Pedro de Alcântara das Torres). Other southern provinces (Santa Catarina and Paraná) received colonists as well. Most migrants came as Wehrbauern, working the land and integrating at the same time into the first battalion of foreigners in the Imperial Brazilian Army. They came from the German states along the Rhine, including Rhenish Prussia (Rheinland), the Bavarian Palatinate and Baden, but also from Mecklenburg and the Hanseatic cities of Hamburg and Bremen. Between 1844 and 1874, this community grew all over Brazil, as national and provincial legislation was implemented in order to increase migratory flows in concurrence with the gradual abolition of slavery. A total of 17,000 Germans arrived in the province, mostly-and again-from the states along the Rhine, Saxony, Hanover and from the eastern Prussian province of Pomerania. ${ }^{17}$ While several colonies were created in different states, Rio Grande do Sul consolidated its status as the cradle of German immigration in the country, with the foundation of colonies such as Santa Cruz (1851), Conventos (1855), Nova Petrópolis (1858) and Teutonia (1858), among others. ${ }^{18}$ While about 50,000 people moved to Brazil during three subsequent migratory waves (1874-89; 1889-1914; 1914-39), the first two migratory waves described above constituted the core of German migration analysed in this paper. As this process coincided with the political unification of the German state (1871), colonos in southern Brazil were targeted by nationalist discourses of 'Germanness' (Deutschtum) and measures of ethnic solidarity taken by churches, societies and individuals could be perceived. ${ }^{19}$

German migration in southern Brazil obeyed climatic considerations as well. In fact, São Leopoldo and the other colonies that were established during this time in subtropical latitudes supposedly confirmed theories that supported the later discourse of human health attached to tropicality. In line with the climatology of the time, proponents of German migration to Brazil such as Oscar Cannstatt and Traugott Bromme emphasised that Europeans might not be suited to living in the tropics, claiming German settlements north of Rio de Janeiro were impossible. ${ }^{20}$ The Eurocentric notion of 'neo-Europes' seemed to have met Rio Grande do Sul inasmuch as the southernmost province of the empire was able to support a denser contingent of temperate migrants. ${ }^{21}$

17 Olgário Paulo Vogt, A colonização alemã no Rio Grande do Sul e o capital social (Santa Cruz do Sul: UNISC, 2006).

18 Jorge Luiz da Cunha, Os colonos alemães de Santa Cruz e a fumicultura: Santa Cruz do Sul (1849-1881) (Curitiba: UFPR, 1988), 298.

19 Frederik Schulze, Auswanderung als nationalistisches Projekt: ,Deutschtum ' und Kolonialdiskurse im südlichen Brasilien (1824-1941) (Cologne: Böhlau, 2016), 16, doi.org/10.7788/9783412506810.

20 Paul Sutter, 'The tropics: A brief history of environmental imagery', in The Oxford handbook of environmental history, ed. A. Isenberg (Oxford and New York: Oxford University Press, 2014), 186.

21 Crosby, Ecological Imperialism, 206. 
Overall, German rural migration in southern Brazil meant forest colonisation. Up to the 1850s, central European agriculture relied heavily on forest resources, and therefore colonists were able to incorporate the woods into their agrarian cycle in South America. However, the Atlantic rainforest was commonly perceived as a sort of environmental otherness, demanding precise technologies, knowledge and practices for its management. Thanks to an ever-growing media landscape in the German states, new graphic technologies, vibrant commercial bonds between Brazil and the different parts of Germany, and growing rates of literacy among the lower strata of German society, broader layers of the German public could access information regarding the environmental conditions of agricultural production in Rio Grande do Sul. ${ }^{22}$ Moreover, the intense exchange of migrant experiences through letters and the onset of a nationalism of global scope permitted augmented knowledge and power over southern Brazilian landscapes as well. Broadly speaking, a polycentric cultural zone had formed, claiming that Germans should choose decidous/semideciduous forests to colonise, avoiding grasslands and pine forests that covered the northern uplands. Moreover, slash-and-burn cultivation was resorted to as the solution for converting the so-called Urwald (primeval forest) into arable. Local farmers, Indians, state officials, businessmen, clergy and other actors contributed to the diminishing of the blanks in knowledge as well.

The category of 'subtropical climate' played a pivotal role in attracting the first agriculturalists among the Germans in Rio Grande do Sul. One of the most noted traits of local weather was the possibility of extending their known agricultural calendar. In comparison to the northern and western German-speaking landswhose agriculture in the nineteenth century was limited, respectively, to 150 and 200 days per year-Rio Grande do Sul admitted a virtually limitless cultivation due to the seasons, temperature, precipitation and photoperiodic patterns. ${ }^{23}$ However, distinctions between a humid/cold wintertime and a relatively dry/warm summertime shaped the progress of agricultural practices. Slash-and-burn cultivation was more efficient after the cold and more humid season, and from September to late October, colonists used to cut the forests and bushes; after some weeks of dry and warm weather, the biomass displaced onto the soil, along with fallen leaves (forest litter) produced by subtropical deciduous trees, could then receive the nourishing flames. The local climate also became responsible for altering the European pattern of summer and winter cereals (Sommergetreide and Wintergetreide, respectively); Rio Grande do Sul allowed only a single harvest of wheat, rye, oats or barley per year, demanding the cultivation of other crops. ${ }^{24}$

22 Thomas Nipperdey, Deutsche Geschichte 1800-1866: Bürgerwelt und starker Staat (Munich: Beck, 1994), 587; Débora Bendocchi Alves, 'Cartas de imigrantes como fonte para o historiador: Rio de Janeiro-Turíngia (1852-1853)', Revista Brasileira de História 23, no. 45 (2003): 161, doi.org/10.1590/S0102-01882003000100007; Susanne M. Zantop, Kolonialphantasien im vorkolonialen Deutschland (1770-1870) (Berlin: Erich Schmidt, 1999), 229.

23 Gustav Gassner, 'Beiträge zur physiologischen Charakteristik sommer- und winterannueller Gewächse, insbesondere der Getreidepflanzen’, Zeitschrift für Botanik 10, no. 1 (1918): 460-1.

24 Gustavo Königswald, Rio Grande do Sul (São Paulo: The author, 1898), 81. 


\section{Italians}

As for the Italians, over about a 30-year period, from 1875 to 1914 , between 80,000 and 100,000 Italian immigrants, to this day known as Italian gringos, came to the southern region of Brazil. ${ }^{25}$ They mainly occupied a large upland territory measuring about $5,000 \mathrm{~km}^{2}$ located in the north-eastern part of the state of Rio Grande do Sul, about $100 \mathrm{~km}$ north of the capital city of Porto Alegre. ${ }^{26}$ The majority of Italian families that settled on the uplands of Rio Grande do Sul came indeed from densely populated mountain areas in the northern regions of the Veneto (54 per cent) and Lombardy (33 per cent) and gladly migrated away from a piece-rate work system to the promise of small land ownership. ${ }^{27}$ In a relatively short amount of time, 84 independent districts were created, today divided into 55 municipalities. ${ }^{28}$ Yet, the so-called Serra Gaucha was far from being an urbanised territory. Sitting on the north-eastern part of Rio Grande do Sul between the River Antas to the north and the German settlements situated on the deltas of the rivers Taquarí and Caí, this upland territory possesses unique geographical characteristics for a mainly tropical and subtropical territory such as Brazil. The entire colonial zone was situated on the southern part of the so-called Paraná Plateau, a high tabular upland composed of sedimentary rocks covered by a diabase layer, reaching over 1,200 $\mathrm{m}$ in height. As a consequence, climatic patterns in the region are quite unusual for Brazil, presenting hot summers, but also cold winters with frost and snow. ${ }^{29}$

Until the early 1870 s, this upland territory was almost entirely occupied by forestsrespectively, subtropical rainforest at lower altitudes $(300 \mathrm{~m}$ to $500 \mathrm{~m}$ ), and wild pine forests starting from $500 \mathrm{~m}$ altitude and reaching peaks of $900 \mathrm{~m} .{ }^{30}$ Climatic conditions were harsher than the rest of the country, characterised by hot, dry summers and cold winters, with an annual average precipitation rate of $1,400 \mathrm{~mm} .{ }^{31}$ These environmental characteristics contributed to create an image of this upland region as a pristine wildlife territory, or sertão-literally, 'desert'. Local and national

25 While in other Latin American countries, this term is adopted in order to address foreigners from the United States, in Brazil it indicates foreigners in general. In southern Brazil, given the relatively late migratory wave from Europe, some of these communities are still ironically defined as gringos, especially in the Italian upland territories. For further information see René Ernani, 'Gertz “Gringos” e "alemaos” no Rio Grande do Sul', in Roberto Radünz and Valeria Beatriz Merlotti Herédia, Imigração e sociedade: Fontes e acervos da imigração italiana no Brasil (Caxias do Sul: EDUCS, 2015), 206-31, and Luis Alberto De Boni and Rovilio Costa, Os Italianos do Rio Grande do Sul (Caxias do Sul: UCS [1979] 1984), 68.

26 Euripides Falcão Vieira, Geografia do Rio Grande do Sul: territorialidade-ambientes naturais-sociedade (Porto Alegre: EDIGAL, 2012), 22.

27 Thales de Azevedo, Italianos e Gaúchos. Os anos pioneiros da colonização italiana no Rio Grande do Sul (Porto Alegre: Nação, 1975), 39.

28 Vitalina Maria Frosi and Ciro Mioranza, Imigração italiana no Nordeste do Rio Grande do Sul [first published 1975] (Caxias do Sul: UCS, 2009), 8.

29 Falcão Vieira, Geografia, 70-1.

30 Heinrich A. W. Bunse, O vinhateiro. Estudo etnográfico-lingüistico sobre o colono italiano no RS (Porto Alegre: URGS University Press, 1978), 14-15.

31 Loraine Slomp Giron and Vania Merlotti Herédia, História da imigração italiana no Rio Grande do Sul (Porto Alegre: EST Ediçóes, 2007), 35. 
institutions paid little attention to the various indigenous groups of Kaingang and Xokleng who already inhabited the region. They envisioned developmental policies for the reconversion of the area to industrial agriculture, with the aim of increasing national revenues. ${ }^{32}$

Certainly, their predominantly mountainous origin constituted a strategic advantage for the Italian families who had to settle in the hostile environment of the Serra Gaucha. Nevertheless, adapting to local ecological circumstances remained quite a complex feat in a region that could be considered a full-fledged geographical island. ${ }^{33}$ Italian mountaineers had to immerse themselves into a foreign forest environment, marching for several days along narrow paths in order to reach the mountain peaks and rugged valleys in which were the land plots that the government had allotted them. ${ }^{34}$ Italian settlers had to create ideal conditions for their permanent subsistence, while confronting the ecological competition of local indigenous groups and dangerous wild animals, such as wild boars, ocelots and cobras. ${ }^{35}$ Therefore, in the first migratory stage, neither economic progress nor productivity were the main concerns for the Italian settlers, unfamiliar as they were with such a vast forest environment, especially in comparison with the densely populated hamlets that they inhabited in northern Italy. ${ }^{36}$

In this context of hardship and deprivation, during their first migratory stage Italian immigrants looked more like guinea pigs in the Brazilian government's plan to bring 'civilisation' to the land, rather than skilful pioneers - a common pattern that the environmental history of migrations has started to unveil. ${ }^{37}$ Whilst the success of Italian communities partially relied on a cultural heritage that informed and motivated their everyday modernising efforts, other exogenous factors would play an essential role in the survival of these staunch gringos. ${ }^{38}$ In fact, during the first settlement period, Italian immigrants mainly relied upon a system of subsistence agriculture practised on their own land lots and inspired by traditional practices devised by Kaingang tribes.

Local indigenous communities had inhabited the land for millennia, developing a lifestyle that relied on hunter-gathering practices associated with the ecological peculiarities of the local forest, and on the establishment of mechanisms of environmental control based on collective action. ${ }^{39}$ Among these, a typical activity was slash-and-burn agriculture-namely, the clearing and fertilisation of forest

32 Azevedo, Italianos e Gaúchos, 22.

33 Bunse, $O$ vinhateiro, 45.

34 Azevedo, Italianos e Gaúchos, 101.

35 Luis Alberto De Boni, ed., La Mérica: escritos dos primeiro imigrantes italianos (Caxias do Sul: UCS, 1977), 74.

36 Mário Maestri, 'A travessia e a mata: memória e história na imigração italiana para o RS', Tempos Históricos 2,

no. 1 (2000): 9-38.

37 Armiero and Tucker, Modern Migrations, 8.

38 Manfroi, A colonização, 98.

39 Paulo Afonso Zarth, 'Agricultura e impactos ambientais no planalto do Rio Grande do Sul', in História Ambiental e Migraçôes, ed. E. Nodari and J. Klug (São Leopoldo: Oikos, 2012), 57. 
areas with fire- and the rotation of crops. ${ }^{40}$ This system resulted in the complete fragmentation and diversification of agricultural production in the region, as each family practised subsistence agriculture in its own lot. An account of 1877 edited by the Ministry of Agriculture reported on the cultivation of several native crops furnished by local authorities in the settlements of Conde d'Eu and Dona Isabel, today pivotal urban areas of the region, known respectively as Garibaldi and Bento Gonçalves. These included the cultivation of crops such as corn, tobacco, potatoes, sugar cane, manioc root and beans. ${ }^{41}$ Therefore, unlike the rest of Rio Grande do Sul, in the Italian colonial zone migratory processes were accompanied by the development of polyculture, rather than monoculture. Agricultural development varied according to the seasons and the altitude of the territory. ${ }^{42}$ These basic forms of agriculture were also complemented by hunter-gathering practices traditional to the indigenous people inhabiting the territory. These relied on the rich biodiversity of the local forest (known as mixed Bryophyllum forest), uniting semi-deciduous and evergreen species. ${ }^{43}$ In particular, the ancient coniferous trees known as araucaria constituted a major source of protein intake for early settlers. ${ }^{44}$ Suitable to grow in the poor soils of the Southern Brazilian uplands, these trees produce extremely nutritious fruits-known as pinhöes- that are harvested during the winter. ${ }^{45}$

As small-scale subsistence agriculture started bearing fruit, it became interrelated by practices of animal farming, as different plant species were associated with certain types of cattle, normally European-born breeds that had been brought to the region by Portuguese and German colonisers. ${ }^{46}$ As an example, hay was associated with cows, and corn with pigs and chickens, which in turn provided a resourceful supply of animal proteins and dairy products for local farmers. ${ }^{47}$ Just like in the case of German settlers, in the north-eastern uplands of Rio Grande do Sul, this process was facilitated by national and local institutions that provided Italian families with seeds and tools, especially during the first migratory period, from 1875 to 1889 . Local settlers were assigned small land plots ranging between 30 and 60 hectares, which they were supposed to redeem within five years using agricultural revenues. ${ }^{48}$

Yet, in contrast with the German case, the first years of Italian colonisation were characterised by the substantial difficulty of increasing agrarian revenues beyond the threshold of subsistence. According to the local newspaper $O$ Caxiense, the reason for these difficulties lay in the lack of experience of Italian communities,

40 Manfroi, A colonização, 71-2.

41 Ministerio da Agricultura, Comércio e Obras Públicas (1877), 445.

42 De Boni and Costa, Os Italianos, 86.

43 Nodari and Mundstock Xavier, 'European Immigration', 41.

44 Stuart Clark Rothwell, The old Italian colonial zone of Rio Grande do Sul, Brazil (Porto Alegre: URGS University Press 1959), 30-31.

45 Silveira Haubman, 'Florestas e Importância das Coníferas', Boletim Geográfico do Rio Grande do Sul 8 (1958), 66-7.

46 Haubman, 'Florestas', 67.

47 Bunse, O vinhateiro, 23-4.

48 Azevedo, Italianos e Gaúchos, 152-3. 
former pieceworkers who did not possess adequate resources with which to improve agricultural revenue. ${ }^{49}$ The lack of agricultural skill among Italian immigrants reported in this article is confirmed by a two specialised columns that ran between 1909 and 1910 in the local newspaper La Libertà, containing basic notions of agricultural production for local inhabitants. ${ }^{50}$ Poor agricultural production was also a consequence of the ecological characteristics of the territory: with its rugged geography, alternating hillside areas and tabular hilltop, the highest soils of the Serra Gaucha experienced poor drainage, and their basaltic composition did not favour the absorption of rainwater. ${ }^{51}$ Water supply was indeed one of the main issues for Italian migrants, who sometimes had to walk for an entire kilometre in search for drinkable water. At the same time, lower soils possessed high degrees of acidity and large amounts of iron compounds, and as a consequence were easily subject to erosion. Finally, a high degree of climate variability affected the entire region, characterised by sudden heavy rains, fog, frosts and hail, as well as violent temperature variations during the day. ${ }^{52}$ All these elements constituted dramatic risk factors for agricultural production in the region in the early settlement years, as farmers had to learn to contend with unpredictable environmental factors. ${ }^{53}$ Therefore, while the rudimentary practices of slash and burn could not accommodate the needs of a growing community of ambitious settlers in search of a better life, the system of private land ownership enforced by the Brazilian national government did not necessarily take into account the delicate hydrogeological balance of the territory, and the unprecedented demographic pressure put a strain on the region. ${ }^{54}$

While slash-and-burn practices had allowed Italian immigrants to survive during their early settlement stage, the environmental threat posed by deforestation and the problems with agricultural production constituted major concerns for Italian colonisers. ${ }^{55}$ As the native forest disappeared and demographic pressure increased in the region, Italian families were confronted with the challenge to devise alternative productive activities that would ensure subsistence while addressing arising ecological issues. ${ }^{56}$ If the socioenvironmental challenges faced by Italian

\footnotetext{
49 O Caxiense 1 , no. 2 (1897).

50 These were entitled 'Notions of Modern Agriculture' and 'Section of the Colonos'. For more information, see La Libertà 1, nos 1-59 (1909-10).

51 Euripedes Falcão Vieira and Susana Salum Rangel, Rio Grande do Sul: Geografia Física e Vegetação (Porto Alegre: SAGRA, 1984), 70-1.

52 Rovilio Costa et al., Imigração italiana no Rio Grande do Sul: vida, costumes e tradiçôes [first published 1974] (Caxias do Sul: UCS, 1986), 24.

53 Rothwell, The old Italian colonial zone, 29-33.

54 Flávia La Salvia and Nilbiamater Silsear Berlese Handschunch 'Processo de colonização no Rio Grande do Sul', Boletim Geográfico do Rio Grande do Sul 17 (1974): 3-43.

55 These concerns were documented by the Italian Consul, Umberto Ancarani, in 1905, who questioned the future resilience of the colonial zone and foresaw a socioenvironmental crisis. For further information, see Umberto Ancarani, 'La Colonia Italiana di Caxias' (Ministero degli affari esteri, bollettino dell'emigrazione, 19) (Rome: Tipografia Nazionale Bertero, 1905), 12-13.

56 Raymond Pébayle, 'Os Viticultores do Rio Grande do Sul', Boletim Geográfico do Rio Grande do Sul 16 (1973), $51-77$.
} 
immigrants were therefore much more critical in contrast to their German peers, both communities seemed to struggle to find an ideal form of land use during their early migratory stage. In both cases, the German and Italian communities embraced one of two crops whose genetic characteristics allowed them to thrive in the colonial zones that they had been assigned-respectively, potatoes for Germans and vines for Italians. Ironically, while these two species reminded German and Italian immigrant communities about their respective homelands, in both cases they were originally 'American' crops that these two European groups contributed to popularising on the Southern American rim of the Atlantic. ${ }^{57}$

\section{The 're-Americanisation' of potatoes}

In comparison to the agricultural patterns proposed by subsequent migratory groups, Germans implemented a more native agriculture. The adoption of local crops came notwithstanding efforts in transplanting the agronomic repertoire of central European agriculture to southern Brazil. However, by the time German colonos settled in Rio Grande do Sul, differences between supposedly native and exotic crops had lost their absolute connotation, inasmuch as German agriculture had already adopted crops from the New World since the seventeenth century. ${ }^{58}$

The most emblematic crop in this sense was the potato: originally domesticated in the Andean highlands, it entered Europe during the sixteenth century. In the former German states, the arrival of this crop has been attributed to Charles de l'Écluse or Carolus Clusius de Antwerp (1526-1609), a Renaissance botanist who introduced the plant to his fellow court gardeners in Germany. ${ }^{59}$ In the following centuries, the prestige and acceptance of the potato would grow considerably in the Germanspeaking lands. It even became a geopolitical tool as the Prussian state promulgated the Kartoffeledikt von Potsdam (1756) with the aim to improve the nutrition of soldiers and preventing the complete destruction of cultivated fields during times of warfare. ${ }^{60}$

57 Even though vines are obviously not originally American, the specific variety that Italian communities in southern Brazil successfully harvested is Vitis labrusca, most particularly the Isabella grape variety, a variety first selected in the United States.

58 Hans-Heinrich Müller, 'Domänen und Domänenpächter in Brandenburg-Preußen', in Moderne preußische Geschichte, 1648-1947. Eine Anthologie, ed. Otto Büsch and Wolfgang Neugebauer (Berlin and New York: De Gruyter, 2013), 321-3.

59 Ellen Messer, 'Potatoes (White)', in The Cambridge world history of food, ed. K. F. Kiple and K. C. Ornelas (Cambridge and New York: Cambridge University Press, 2000), 190-1, doi.org/10.1017/CHOL 9780521402149.023.

60 Hartmut Harnisch, 'Peasants and markets: The background to the agrarian reforms in feudal Prussia East of the Elbe, 1760-1807', in The German peasantry: Conflict and community in rural society from the eighteenth to the twentieth centuries, ed. R. J. Evans and W. R. Lee (London: Croom Helm, 1986), 64-7. 
The potato became a pivotal element of the Agrarian Revolution between the eighteenth and nineteenth centuries, since its cultivation permitted the development of crop rotation and the intensification of agriculture and husbandry. Potatoes pushed productivity higher as long as they were cultivated in areas that used to be left fallowaccording to long-established practices related to the three-field system. ${ }^{61}$ With the intensification of land, livestock farming and fertilisation, the spread of potato fields throughout fallow land followed synchronically the development of barn facilities among peasants and farmers. The surplus in the field was then channelled to the stables and provided an additional source of calories for the livestock. Cattle, for instance, could produce more manure than the usual quantities, with the advantage of sedimentation of the dung in a concentrated place, allowing further and more accurate fertilisation of the fields. Such measures formed the core of the so-called rational agriculture as proposed by Albrecht Thaer (1752-1828), who combined expertise in natural sciences and an international reputation with concrete agrarian policies under the Prussian monarchy. ${ }^{62}$ Potatoes also became a cheap source of food for an agrarian society that still had to endure famines and multiple hazards. ${ }^{63}$ Besides that, the tuber changed eating habits from Ireland to Russia, transforming food traditions markedly. ${ }^{64}$

By 1824, Germans had already mastered the cultivation of potatoes in former farmland that had been abandoned because of loss of fertility. Eastern Germans were presumably more accustomed to its cultivation, because crop rotation was generally accepted earlier and more easily by the aristocratic and commercial agriculture of the region. ${ }^{65}$ Western Germans, and especially the migrants from the Hunsrück and Eifel regions - both of them part of the Prussian Rhineland — were still shifting towards crop rotation. There, potatoes were only cultivated in some tracts of fallow lands, which were not completely abandoned up to the end of the nineteenth century. ${ }^{66}$ Nevertheless, Johann Nepomuk von Schwerz, Albrecht Thaer's close collaborator, observed in 1831 during a research survey across the Hunsrück that peasants foddered their livestock with both raw and cooked potatoes. ${ }^{67}$

61 Wulf Diepenbrock, Frank Ellmer and Jens Léon, Ackerbau, Pflanzenbau und Pflanzenzüchtung: Grundwissen Bachelor (Stuttgart: UTB, 2016), 143.

62 Albrecht Daniel Thaer, Grundsätze der rationellen Landwirtschaft (Berlin: Reimer, 1821), 235.

63 Massimo Montanari, Der Hunger und der Überfluß: Kulturgeschichte der Ernährung in Europa (München: Beck, 1995), 155-6.

64 Kenneth Pomeranz and Steven Topik, The World that Trade Created: Society, Culture, and the World Economy, 1400 to the Present (Armonk, NY, and London: M. E. Sharpe, 2006), 138.

65 Ludwig Biewer, Kleine Geschichte Pommerns (Bonn: Bund der Vertriebenen, 1997), 19.

66 Lothar Müller, Die Landwirtschaft auf dem Hunsrück: unter besonderen Berücksichtigung der des Kreises Simmern (Bonn: Carl Georgi, 1906), 137-8.

67 Johann Nepomuk Hubert von Schwerz, 'Beiträge zur Kenntnis der Landwirtschaft in den Gebirgsgegenden des Hunsrücken', Möglischen Annalen der Landwirtschaft 27 (1831): 16-17. 
The arrival of Germans in southern Brazil may be seen as a process of re-Americanising of the potato, at least in terms of South America. This historical process implied the introduction of European-cultivated seedlings/tubers in the continent where potatoes are deemed to be native. Furthermore, the potatoes brought by the Germans into southern Brazil in the nineteenth century were by no means equal to the ones dispersed by the Columbian Exchange inasmuch as centuries/decades of cultivation in European fields had exposed potatoes to different evolutionary processes. ${ }^{68}$ Quite interestingly, in the early nineteenth century the Andean tuber was strikingly unusual for most of Brazilian society and neighbouring countries-but still pivotal in the Andean altiplano. While indigenous groups like the Kaingang, Xokleng and Guarani still cultivated some potato species such as white potatoes (Solanum tuberosum) and the batatinha (Oxalis spp. and Canna glauca), such production was carried out only on a local scale. Moreover, these territories were often located far from urban settlements and therefore unreachable for broader markets. ${ }^{69}$ In addition, cassava (Manihot esculenta) was the most prominent crop of indigenous forest agriculture, leaving potatoes far behind in terms of gross production. ${ }^{70}$ It comes as no surprise that prior to German migration, urban residents in Brazil had access to the potato only through imports from Great Britain; as a reflection of this, the regular potato is still called Batata inglesa in Brazil. ${ }^{71}$ From the 1850s, the German colonies of São Leopoldo and Santa Cruz were responsible for 95 per cent of the potatoes consumed in the biggest cities of Rio Grande do Sul. The prominence of the Germans in dealing with the potato and their dominance of local, national and even international markets contributed to the formation of imagined ethnic frontiers posited by travellers like the physician from Lübeck Robert Avé-Lallemant. In the late 1850s, he went so far as to emphasise the inner identity between potato cultivation and Germanness in Rio Grande do Sul. ${ }^{72}$ Moreover, Brazilian nationals very soon nicknamed and labelled Germans with the term alemão-batata, literally 'potato-German'. ${ }^{73}$

68 By 1854, there were 186 varieties of potato in the German states. See John Reader, Potato: A History of the Propitious Esculent (New Haven, CT: Yale University Press, 2009), 217.

69 Francisco Silva Noelli, 'A ocupação humana na região sul do Brasil: arqueologia, debates e perspectivas, 18722000', Revista USP 44, no. 1 (1999/2000): 246-55.

70 Henrique Ataide da Silva and Rui Sérgio Sereni Murrieta, 'Mandioca, a rainha do Brasil? Ascensão e queda da Manihot esculenta no estado de São Paulo', Boletim do Museu Paraense Emílio Goeldi. Ciências Humanas 9, no. 1(2014): 37-60, doi.org/10.1590/S1981-81222014000100004.

71 Redcliffe N. Salaman, The History and Social Influence of the Potato (Cambridge: Cambridge University Press, 1985), 132-3.

72 In fact, German-Brazilian potato production reached first the markets of Rio de Janeiro and soon afterwards the markets of Buenos Aires (in the late nineteenth century) (Jose Antonio Pimenta Bueno, Relatório da provincia de S. Pedro do Rio Grande do Sul, o conselheiro Jose Antonio Pimenta Bueno, na abertura da Assemblea Legislativa Provincial no. 1. O de outubro de 1850, acompanhado do orçamento da receita e despeza para o anno de 1851 (Porto Alegre: Typ. de F. Pomatelli, 1850)). For information see Robert Avé-Lallemant, Viagem ao sul do Brasil (1858) (Rio de Janeiro: Instituto Nacional do livro, 1953).

73 Jean Roche, Colonização alemã e o Rio Grande do Sul (Porto Alegre: Globo, 1969), 253. 
Potatoes became a key element in terms of agrarian knowledge between Germany and Brazil as well. Knowledge of the potato operated as a translator for exotic and unknown tuber crops like the cará (Dioscorea alata or purple yam) and the white yam (Dioscorea cayennensis subsp. rotundata) inasmuch as books, brochures and other text formats presented their similarities with the potato; but no other tuber was more often compared to the Andean crop than the cassava-Friedrich Gerstäcker and Georg Anton von Schäffer, reputed authors on Brazilian affairs in the German states, claimed such proximities clearly and emphatically. ${ }^{74}$ In the long term, cassava and potatoes came to dominate colonists' gastronomic taste; however, despite having displaced the potato in some European recipes, cassava coexisted on relatively equal terms with the potato in German-Brazilian rural society. ${ }^{75}$ Perhaps more importantly, German colonists in São Leopoldo could dispose of potato staples as soon as 1824. Under the influence of von Schäffer-at the time in charge of recruiting colonists in Europe for São Leopoldo and deeply aware of the pivotal role played by the potato in central European agriculture-the imperial government supplied the newcomers with the precious tubers. ${ }^{76}$

In Rio Grande do Sul, potato cultivation developed satisfactorily, following a shared global sense that its cultivation was more likely to be successful outside tropical latitudes. ${ }^{77}$ In contrast to Prussia, for instance, the climate of southern Brazil enabled on average two harvests per year. ${ }^{78}$ The most acute differences in terms of agrarian practices happened when colonists were pioneering new and forested areas, because stumps, logs and roots prevented for some years the usage of the plough and the harrow even after deforestation and burning; in addition, land clearance used to occur with limited inputs of manure, since German pioneers normally did not possess enough livestock for composting the soil; however, that could be compensated for by slash-and-burn agriculture, which improved the nutrition of the soil and avoided acidification. ${ }^{79}$ Letters written by colonists and published in the German-speaking lands in the 1850s reported the harvest of potatoes directly from the forest (batata silvestre), a fact that opens new questions about either the likely reutilisation of fields abandoned by indigenous farmers, or the invention of shortlived techniques. ${ }^{80}$ Some years after deforestation, German colonos often resorted

74 For further information, see Friedrich Gerstäcker, Die Colonie: Brasilianisches Lebensbild (Leipzig: Hermann Costenoble, 1864), 43; and Georg Anton von Schäffer, Brasilien als unabhängiges Reich: In Historischer, Mercantilischer und Politischer Beziehung (Altona: Hammerich, 1824), 315.

75 Hans Porzelt, Der deutsche Bauer in Rio Grande do Sul (Ochsenfurt am Main: Fritz \& Rappert, 1937), 56-8.

76 Carl Friedrich Gustav Seidler, Dez anos no Brasil: eleiçôes sob Dom Pedro I, dissoluçấo do Legislativo, que redundou no destino das tropas estrangeiras e das colônias alemãs no Brasil (Brasília: Senado Federal, 2003), 169.

77 Kenneth Pomeranz, The Great Divergence: China, Europe, and the Making of the Modern World Economy (Princeton, NJ, and Oxford: Princeton University Press, 2009), 58, doi.org/10.2307/j.ctt7sv80.

78 Hermann Von Ihering, Rio Grande do Sul (Gera: Weltpost-Verlag 1885), 124.

79 Nelson Novaes Pedroso Júnior, Rui Sérgio Sereni Murrieta and Cristina Adams, 'A agricultura de corte e queima: um sistema em transformação', Boletim do Museu Paraense Emílio Goeldi. Ciências Humanas 3, no. 2 (2008): 153-74, doi.org/10.1590/S1981-81222008000200003.

80 Alves, 'Cartas de imigrantes', 178. 
to fertilising the resulting arable lands, with the usage of the plough and harrow. The tuber continued to perform its role as a crop of global scope that grows on volcanic soils because in both central Europe and southern Brazil, the potato was a pivotal character of traditional slash-and-burn agriculture. ${ }^{81}$

Potato cultivation was also suitable for steep hills, a geophysical reality for many colonists in Rio Grande do Sul. ${ }^{82}$ Yet, more strikingly to the history of biotic acclimatisation, the potato became a buffer crop for agricultural experimentation. German colonisation in southern Brazil demanded above all the ability to face risks; in the pioneering time, cultivating cassava, black beans and local varieties of corn implied managing unknown crops under unpredictable weather conditions. To some extent, German colonists had been trained for the challenge of coping with the environmental otherness of South American ecologies, as mentioned before; the entrusted agent Peter Kleudgen, for instance, wrote a brochure, published in 1853, for the colonists who headed to Santa Cruz stating that the potato 'delivers an extraordinary production without demanding complicated preparation of the field'. ${ }^{83}$ Potatoes provided - at least in the biggest Germanic colonies of Rio Grande do Sul-welcome reliability because they belonged to a familiar agrarian repertoire, an exception in the whole edifice of German-Brazilian agriculture. ${ }^{84}$ This development could be well observed in the colonies Santa Cruz, São Lourenço and São Leopoldo.

As German colonisation gained pace in the late 1840s, newcomers brought with them new varieties of potato that were juxtaposed with local ones. However, the globalisation of the potato was at that time paying a high price for its poor genetic variability, inasmuch as the effects of the potato blight (Phytophthora infestans) were still ravaging production worldwide. Johann Eduard Wappäus identified some diseases existing in the potato in southern Brazil during the early $1850 \mathrm{~s} .{ }^{85}$ While colonists tried to escape the consequences of the 'Hungry Forties' in their homeland, they were possibly bringing sick staples to Rio Grande do Sul. ${ }^{86}$ An anonymous article (possibly written by Peter Kleudgen) entitled 'Santa Cruz' and published by the notorious Allgemeine Auswanderungs-Zeitung in 1854 prescribed the transportation of staples, for instance. ${ }^{87}$ Karl Kirchoff, a colonist who settled in Santa Cruz in

\footnotetext{
81 François Sigaut, 'Swidden cultivation in Europe: A question for tropical anthropologists', Social Science Information 18, nos 4-5 (1979): 679-94, doi.org/10.1177/053901847901800403.

82 Arione da Silva Pereira et al., Produção de batata no Rio Grande do Sul (Circular Técnica, 48) (Pelotas: Embrapa Clima Temperado, 2005).

83 Peter Kleudgen, Die deutsche Kolonie Santa Cruz in der Provinz Rio Grande do Sul in Süd-Brasilien, nach den neuesten Nachrichten dargest (Hamburg: Kittler, 1853), 9.

84 Balduíno Rambo, A fisionomia do Rio Grande do Sul: ensaio de monografia natural (Porto Alegre: Selbach \& Cia, 1956), 311-12.

85 Johann Eduard Wappäus, Handbuch der Geographie und Statistik des Kaiserreiches Brasilien (Leipzig: J. G. Hinrich'schen Buchhandlung, 1871), 1836.

86 Cathleen Catt, 'Farmers and factory workers: Rural society in Imperial Germany. The example of Maudach', in The German peasantry, ed. Evans and Lee, 141-2.

87 Allgemeine Auswanderungs-Zeitung 30 (11 March 1854).
} 
the 1850s, declared that his family brought to Brazil staples and seeds of crops with which they were familiar, potatoes among them. ${ }^{88}$ In this period, potatoes and diseases were travelling across the ocean and the Brazilian authorities readily perceived the genetic causes of the problem through the idea of lack of variation. ${ }^{89}$ Alarmed by plagues affecting cereal production in Rio Grande do Sul since the early 1820s, provincial and imperial officials supplied colonists with new varieties of potato from the 1850 s onward. ${ }^{90}$

German migrants in southern Brazil thus took part in the multisided globalisation of the potato. After some centuries of vigorous success in Europe, Brazil could embrace permanently the potato and, furthermore, its own South American biological-genetic heritage. Since the global expansion of the tuber to other geographies from the early colonial age on, Germans faced the challenges of cropping potatoes under different ecological conditions. The thriving cultivation of the tuber in southern Brazil and its incorporation into some sort of German-Brazilian agronomic culture only became possible due to the globalisation of genetic fluxes, varieties and ecologies.

\section{American grapes}

While German colonos were able successfully to 'reintroduce' potato crops to southern Brazil, reliant on environmental knowledge and ecological practices from their homeland, the transformation of the poor Italian colonial zone into a thriving wine production area was the result of a complex ecological transfer that allowed major environmental and economic transformations in the region. ${ }^{91}$ While since the arrival of German immigrants in 1824 the Brazilian government had invested in agricultural development through a generous policy of land distribution, for Italian communities this process was more troubled, due to contradictory policies, a reduced budget and the harsh geographical characteristics of the territory. ${ }^{92}$ Geographical isolation also compromised trade for Italian colonos, as they had to confront the competition presented by Germans, whose products could be transported to the coastal city of Porto Alegre with more ease. ${ }^{93}$ Moreover, the adoption of slash-

\footnotetext{
88 Cunha, Os colonos alemães, 142.

89 Francisco José de Sousa Soares de Andréa, Relatório do presidente da provincia de Sáo Pedro do Rio Grande do Sul, o tenente General Francisco Jose de Souza Soares de Andrea, na abertura da Assembleia Provincial no 1. de junho de 1849, acompanhado do orçamento da receita e despesa para o anno de 1849-1850 (Porto Alegre: Typographica PortoAlegrense, 1849), 10.

90 Jerônimo Martiniano Figueira de Mello, Fala dirigida à Assembleia Legislativa da provincia de S. Pedro do Rio Grande do Sul pelo presidente, conselheiro Jerônimo Martiniano Figueira de Mello, em a segunda sessao de 14. Legislatura (Porto Alegre: Typographica do Rio Grande do Sul, 1872), 51.

91 Manfroi, A colonização, 69.

92 Luiza Horn Iotti, Imigração e poder. A palavra oficial sobre os imigrantes italianos no Rio Grande do Sul (18751914) (Caxias do Sul: UCS University Press, 2010), 78-9.

93 José Vicente T. dos Santos, 'Cantineros e colonos: a indústria de vinho no Rio Grande do Sul', in RS: Imigração e colonização, ed. J. H. Dacanal and S. Gonzaga [first published 1980] (Porto Alegre: Mercado Aberto, 1992), 139.
} 
and-burn agricultural techniques on an unprecedented scale was starting to take a toll on the ecology of the region, as the disappearance of the forest generated hydrological problems.

Both historical reconstructions and economic studies have emphasised that Italian immigrants found economic and social redemption in the development of the local wine industry. This successful experience began with small-scale family production, allegedly propelled by the need to revive traditions from the Italian homeland through 'the spirit of wine'. ${ }^{4}$ Production was concentrated on the most densely populated areas of land, situated at an altitude between $600 \mathrm{~m}$ and $800 \mathrm{~m}$, and comprising the municipalities of Caxias do Sul, Farroupilha, Garibaldi, Bento Gonçalves and Flores da Cunha. ${ }^{95}$ According to the Italian consul Enrico Perrod, as early as 1881, the area of Garibaldi alone had produced 5,000 hectolitres of wine. ${ }^{96}$ This was the first step in the proliferation of the local wine industry, as the production of wine was later extended to cooperative organisations and a national labour union of wine producers-known as Sindicato do Vinho — was formed in 1929. ${ }^{97}$ The optimisation of the wine industry was supported by technological innovations promoted by national institutions, such as the adoption of small windmills and, later on, of water and vapour machines. ${ }^{98}$ Naturally, the success of the local wine industry was also tantamount to the centralisation of the supply chain, as production was concentrated in the hands of a few entrepreneurs who were able to profit from the import substitution policy launched by the national government during the interwar period. Later, during the 1970s, multinationals from France, Italy, Uruguay, Canada and the United States penetrated the Brazilian national market, fostering internal competition and the diversification of the supply chain. ${ }^{99}$ Today, bioengineering and modern industrial agricultural techniques have allowed the adaptation of several European species to the local Brazilian climate, fostering a sense of extra-national uniqueness in the local wine industry. ${ }^{100}$ According to data from the Brazilian Wine Institute, between 2006 and 2018, the wine industry in the state of Rio Grande do Sul - most of it based in the Italian colonial zone of Serra Gaucha - has produced an average of 207.6 million litres of table wine and 14 million litres of champagne. ${ }^{101}$

94 Roni Blume and Suzimary Specht, 'O uso da noção de terroir para a valorização dos vinhos e promoção do desenvolvimento da regiâo da serra gaúcha, Rio Grande do Sul-Brasil, in IV Congresso Internacional de la Red Sial (Mar Del Plata, Argentina: [n.p.], 2008).

95 Pébayle, 'Os Viticultores', 52.

96 Enrico Perrod, Le colonie brasiliane Conte D'Eu e Donna Isabella (Ministero degli affari esteri, bollettino consolare, 19) (Rome: Libreria dei Fratelli Bocca, 1883), 302.

97 Santos, 'Cantineros', 140-1.

98 Azevedo, Italianos e Gaúchos, 208.

99 Carolina Miranda Cavalcante, 'An Institutional Approach to the History of Wine in Brazil', BIO Web of Conferences 7 (2016), doi.org/10.1051/bioconf/20160703025.

100 Luiz Antenor Rizzon and Alberto Miele, 'Correção do mosto da uva Isabel com diferentes produtos na Serra Gaúcha’, Ciência Rural 35, no. 2 (2005): 450-4, doi.org/10.1590/S0103-84782005000200033.

101 IBRAVIN_-Instituto Brasileiro do Vinho, Comercialização de vinhos_empresas do Rio Grande do Sul_Brasil (2018), www.ibravin.org.br/Dados-Estatisticos, accessed 13 February 2020. 
Economic evaluations aside, historiography agrees in considering the development of the wine industry as the main foundation for a lasting solidarity between the immigrants and the north-eastern uplands of Rio Grande do Sul. ${ }^{102}$ Certainly, the development of the wine industry in southern Brazil favoured the resurgence of material practices and cultural features typical of the Italian peninsula. Southern Brazilian vineyards became a cultural tribute to the homeland as well as a great opportunity for socioeconomic growth for a marginal group of individuals that had constructed its ecological niche in a marginal forest territory. ${ }^{103}$ However, a more careful examination of the historical data demonstrates that the emergence of viticulture in the Italian colonies was not simply the result of previously acquired environmental knowledge, but also the product of the convergence of historical and ecological circumstances. According to several sources, Italian immigrants brought wine species from Italy, such as Barbera, Bonarda, Moscato and Trebbiano, although they soon realised that they would not adapt to the harsh characteristics of the local territory. ${ }^{104}$ In 1905, Umberto Ancarani lamented the scarce acquaintance of Italian colonos with wine production techniques, attributing their failure to cultivate European species to poor environmental knowledge. However, he also observed that the expansion of wine production was fostered by the diffusion in the region of a wine species from North America known as Isabella, a variety that generated a 'weak, sour and strawberry-flavoured' quality to the wine. ${ }^{105}$

Allegedly originating in Spain and commonly considered as a hybrid of Vitis vinifera and Vitis labrusca, the Isabella variety started gaining recognition in the Brooklyn garden of Colonel George Gibbs around 1816, and was renamed after his wife, who had obtained it from North Carolina. ${ }^{106}$ An 1846 essay praised it as a particularly adaptive grape variety that could easily be cultivated in non-ideal contexts: 'it may be placed in a corner of any roof or space which may be desired. It shelters the domestics at their labour, and soap-suds is an excellent manure for its roots. Its qualities are known and respected even among the Vines of Europe'. ${ }^{107}$ Between 1839 and 1842, a couple of decades after its diffusion in North America, the plant had been shipped to southern Brazil by Thomas Maister, reaching German immigrants in the regions of Rio dos Sinos and Caí sitting at the foot of Serra

102 Juliana Bublitz, 'A Eco-História da colonização italiana no Rio Grande do Sul', ANPUH-XXIII Simpósio Nacional de História: História, guerra e paz (Londrina: Universidade Estadual de Londrina, 2005), 2.

103 Vanessa Manfio and Vinício Luís Pierozan, 'Território, cultura e identidade dos colonizadores italianos no Rio Grande do Sul: uma análise sobre a Serra Gaúcha e a Quarta Colônia’, GEOUSP Espaço E Tempo 23, no. 1 (2019): 144-62, doi.org/10.11606/issn.2179-0892.geousp.2019.146130.

104 'Cinquantenario della colonizzazione italiana nel Rio Grande del Sud', La cooperazione degli italiani al progresso civile ed economico del Rio Grande del Sud (Porto Alegre: Posenato Arte e Cultura, 2000), 201.

105 Ancarani, 'La Colonia Italiana', 18 (authors' translation).

106 Thomas Pinney, A History of Wine in America, vol. 1: From the Beginnings to Prohibition [first published 1989] (Berkeley, CA: University of California Press, 2007), 190-2.

107 Alder Jermain Spooner, The Cultivation of American Grape Vines, and Making of Wine (New York: Spooner \& Co., 1846), 16, doi.org/10.5962/bhl.title.36952. 
Gaucha. While the plant had no particular success among German colonos, it thrived among Italian communities, who nostalgically embraced familiar wine production as a tribute to their lost heritage. ${ }^{108}$

Other ecological factors played a central role in this successful experience. The genetic characteristics of the Isabella-also known as the 'fox grape'-were particularly suitable for the upland environment of north-eastern Rio Grande do Sul. Due to its environmental and spatial adaptability, the Isabella was very easy to propagate in the rugged territories of the Serra Gaúcha. As a deciduous species, it was resistant to the cold winters and climatic imbalances that characterised the region. Perhaps more importantly, its biological qualities allowed it to resist fungal diseases such as odium and to the plague of phylloxera, a crucial factor in a rudimentary agricultural context such as that of the early Italian colonies. ${ }^{109}$ This allowed the massive cultivation of the plant in the Italian region of Rio Grande do Sul, an unprecedented result for a wine species. Indeed, previous attempts to introduce European wine varieties in the country, carried out by the Jesuit missionary St Roque González de Santa Cruz in 1626 and by mariners from the Azores in 1752, had surrendered to the harsh climatic conditions of the region. ${ }^{110}$ Thus, although commonly defined as an inferior grape due to its lack of the conventional organoleptic characteristic of Vitis vinifera (most notably a low sugar content), the Isabella variety proved suitable for local environmental circumstances, allowing for the expansion of the wine industry in the region. ${ }^{111}$ In a few decades from its introduction, the Isabella became officially known as vinho de colônia. In 1914, the Italian consul Ranieri Venerosi Pesciolini confirmed the prominence of the Isabella variety in the local wine industry, in spite of the multiple attempts of Italian communities to introduce other European species. ${ }^{12}$

Whilst no other species was as successful as the Isabella, attempts to improve its quality have been made since the 1890s, with the development of hybrids from European seedlings imported by the government of Rio Grande do Sul. Agronomic governmental organisations, such as the Estação Experimental de Agronomia and the Estação Experimental de Viticultura e Enologia, were also created as a consequence. ${ }^{113}$ At the same time, several cooperatives began to be formed from the early 1910s, with the aim to guarantee the overall quality of the product and prevent harmful

108 Janaíne Trombini and Luís Fernando da Silva Laroque, 'Atividades Agrícolas dos Imigrantes Italianos e seus Descendentes na Macrorregiāo Oeste do Vale do Taquari, Rio Grande do Sul/Brasil', Fronteiras: Journal of Social, Technological and Environmental Science 6, no. 3 (2017): 122-40, doi.org/10.21664/2238-8869.2017v6i3.p122-140. 109 Luiz Antenor Rizzon, Alberto Miele and Júlio Meneguzzo, 'Avaliação da uva cv. Isabel para a elaboração de vinho tinto', Ciência Tecnologia Alimentícia 20, no. 1 (2000): 115-21, doi.org/10.1590/S0101-20612000000100022.

110 Carlos Henrique Machado Rodrigues, 'A indústria vinícola gaúcha e o capitalismo: um universo de lutas e sobrevivência', Ciências e Letras 41 (2007): 101-18.

111 Jancis Robinson and Julia Harding, The Oxford Companion to Wine [first published 1994] (Oxford: Oxford University Press, 2015), 379, doi.org/10.1093/acref/9780198705383.001.0001.

112 Ranieri Pesciolini Venerosi, Le colonie italiane nel Brasile Meridionale (Turin: Fratelli Bocca, 1914), 62.

113 Rodrigues, 'A indústria', 106. 
chemical manipulations. ${ }^{114}$ Italian communities were therefore able to bring their traditional affection for viticulture to the north-eastern plateau of Rio Grande do Sul, laying the foundation for a prosperous enterprise that would become the most distinguishing feature of the region. As early as 1884 , the diffusion of domestic wine production was already a distinguishing feature of the region, as witnessed by a letter of the Italian immigrant Paulo Rossato, who described in amazement the rapid growth of the vines that were planted in each household in the Italian colony of Caxias do Sul:

What they said it's true: with a small number of vines, they are able to [fill] a large amount of wine barrels. This because they do not plant vines in the fields like in Italy: they plant them next to their houses, using a two metre arbour on which vine branches can grow. In three years time, with only 15 branches they obtain a barrel of good wine. And you cannot imagine how a vine can grow here in three years. ${ }^{115}$

In a similar fashion, in 1897 O Caxiense envisioned a great year for the harvest and production of wine, describing a 'luxurious and promising' vineyard, in spite of the cold winter that had characterised the season. ${ }^{116}$ Certainly, the expansion of the wine industry gave Italian communities a chance to reproduce some of the agrarian patterns that characterised their homeland, although with due differences. ${ }^{117}$ Industrial wine production was aided and complemented by the development of the lumber industry in the states of Rio Grande do Sul and Santa Catarina, leading to the quick exploitation of the precious local tree species, determining a dramatic environmental change that favoured wine crops. ${ }^{118}$ Naturally, this produced major changes in the local landscape: in a few decades the rainforest was replaced by the so-called 'sacred Mediterranean pair', consisting of vines and wheat plantations. ${ }^{119}$ Typically Mediterranean tree species were complemented by the proliferation of local vegetation, most notably the so-called capoeira shrubs, extensively used during the fallow period after forest clearing, as a result of agricultural rotation techniques. ${ }^{120}$ This produced the meaningfully fragmented proto-Mediterranean landscape that still characterises the uplands of north-eastern Rio Grande do Sul to this day, at the expense of the native forest, of which only 1 per cent survived this transition. ${ }^{121}$ The only three species that survived this massive environmental transformation were

114 Pesciolini Venerosi, Le colonie, 104-5.

115 In De Boni, La Mérica, 31-2 (authors' translation).

116 O Caxiense 1, no. 2 (1897).

117 Frosi and Mioranza, Imigração, 94-95.

118 Nodari and Mundstock Xavier, 'European Immigration', 47.

119 Balduíno Rambo, 'A zona de colonização italiana-estudo geográfico', in Álbum comemorativo do $75^{\circ}$ aniversário da colonização italiana no Rio Grande do Sul (Porto Alegre: Globo, 1950), 144.

120 Rothwell, The old Italian colonial zone, 31.

121 José Alberto Moreno, 'Uso da Terra: Vegetação Original e Atual do Rio Grande do Sul', Boletim Geográfico do Rio Grande do Sul 15 (1972): 45-51. 
the result of conservation policies aimed at protecting some forest areas, for both aesthetic and practical reasons. Indeed, species such as pines, palms, sycamores and Chinaberry trees (Melia azedarach) were used for the construction of houses. ${ }^{122}$

The encounter of a foreign species such as Isabella with the Italian viticultural tradition was the spark that ignited the development of vineyards all over the Serra Gaucha, a crucial element for the economic prosperity of the region even before the creation of cooperatives and the introduction of mechanised techniques that optimised agricultural production. The introduction of this sturdy wine species, resistant to fungal diseases and to adverse climatic conditions, was a decisive factor for the environmental resilience of the region, whose biological life had been radically modified in just a few decades since the migratory phenomenon. The Isabella allowed Italian colonos to recreate a thriving proto-Mediterranean landscape on the ashes of a dying forest biome, thus avoiding a major ecological crisis and the displacement of entire settlements. Not coincidentally, as early as 1914, wine production in the central city of Caxias do Sul was already described in consular reports as the main industry. ${ }^{123}$ In this sense, the successful colonial experience of Italian immigrants was more related to the biological characteristics of the Isabella vine plants than to specific environmental knowledge associated with national cultural identity. On the other hand, their affection for viticulture allowed Venetian communities to create a syncretic agricultural experience in a changing upland ecosystem, a wine variety previously selected in North America. This convoluted yet remarkably effective pastiche resulted in the creation of the Italian-Brazilian culture that today uniquely permeates the uplands of north-eastern Rio Grande do Sul, successfully synthesising transnational cultural practices and multi-species ecological features. Certainly, the massive conversion of the territory's agricultural patterns was part of a national political agenda aimed at increasing the country's economic revenues by converting allegedly pristine wildlife areas to intensive agriculture. ${ }^{124}$ However, this process would have resulted in a major environmental catastrophe had Italian immigrants not stumbled upon this sturdy wine species that would leave an indelible mark on the agrarian characteristics of the region. The experience of wine production would indeed set the tone for the massive conversion of the region to industrial agriculture in the 1970s, with the so-called 'green revolution'. ${ }^{125}$ Thus, what is today known as one of the most Mediterranean environments outside Europe is actually a hybrid landscape, resulting from the syncretic encounter of local species domesticated for centuries by indigenous people and an imported plant species.

122 De Boni and Costa, Os Italianos, 131-41.

123 Pesciolini Venerosi, Le colonie, 44.

124 Manfroi, A colonização, 19.

125 Marcos Gerhardt and Rossana Petry Nedel, 'Uma História Ambiental da Modernização da Agricultura no Noroeste do Rio Grande do Sul', in Tecnologia e Agricultura Familiar. Uma Relação de Educação, ed. A. Andrioli (Ijuí: Editora Unijuí, 2009), 77-8. 


\section{Toward an evolutionary history of migrations}

Both Germans and Italians faced similar socioenvironmental challenges toward the beginning of their migratory experiences in the southernmost Brazilian (Rio Grande do Sul). Yet, specific cultural inputs from their homelands and the different environmental challenges presented by the geographical regions that they occupied led to divergent migratory trajectories. While both communities relied on slashand-burn techniques acquired from local indigenous groups in their early migratory period, Germans possessed better cultural tools and more favourable environmental circumstances with which to convert their territory into intensive agriculture without compromising the ecological balance of the region. In contrast, Italians had to confront the harsh environmental circumstances of the Brazilian upland territories with little specific environmental knowledge. This divergence was exacerbated in the following decades, as Germans and Italians engaged in agricultural practices related to two different crops - potatoes and vines, respectively. While the difference between these crops denoted a stark environmental gap between the two colonial regions, they were equally responsible for the successful agricultural experience of both the German and the Italian communities. If during their first migratory stages Italian immigrants almost caused a major socioenvironmental catastrophe for the region, the almost complete destruction of the Atlantic rainforest in the north-eastern uplands of Rio Grande do Sul was compensated by the installation of a pioneer wine species, able to relentlessly thrive on arid soils and to resist the climatic imbalances of the region. The prosperous growth of this sturdy species in the uplands of Serra Gaucha allowed surprised Italian colonos to create a proto-Mediterranean identitarian landscape in the region, symbolically aligned with the traditions of their homeland while at the same time successfully embodying one of the most peculiarly successful examples of Brazilian agricultural entrepreneurship. At the same time, not even the informed German colonos, with their homeland knowledge of environmental conservation, could have foreseen the tremendous impact of potato crops in the colonial zone of Rio Grande do Sul that they occupied. Surely Germans had long been acquainted with potato cultivation in Europe-although between the 1840s and 1850s, the tuber was showing its genetic limits, due to poor variation. Conversely, in Brazil, other varieties could be combined with European ones_-along with other environmental features like solar radiation, mild temperatures and precipitation-enabling cultivators to double production. Moreover, the South American origin of the potato and reports about its suitability to southern Brazil turned the potato into sort of a safe buffer for further agricultural experimentalism.

Today both the Italian and the German migratory experience in Rio Grande do Sul constitutes one of the most acclaimed examples of human skilfulness and resilience, as witnessed by the multiple celebratory activities promoted both at a local and at a national level. The myth of the resourceful and skilled European pioneers able to reshape a hostile landscape in their image continues to permeate historical accounts and political discourse. However, a careful examination of the history 
of this migration phenomenon, informed by the critical tools of environmental history, reveals a much more complex and controversial picture than that provided by conventional historical accounts.

Challenging the celebratory tone of traditional historical reconstructions, this study has demonstrated that both the development of potato plantations in the German colonial zone and the wine industry in the Italian upland colonies were the result of a multilayered set of historical circumstances in which human and non-human actors intermingled and meaningfully influenced each other. In this sense, the history of European migrations to Brazil described here should be interpreted as the result of a co-evolutionary process in which cultural features, local environmental circumstances and exogenous ecological factors meaningfully intermingled. As these European communities embarked on a migratory journey in a foreign land lying on the other side of the ocean, their homeland culture intermingled with the cultural and ecological circumstances that they encountered in the new territory. Perhaps more importantly, while these communities strove to construct their ecological niche in a foreign environment, they found unexpected allies in other natural species, whose characteristics were particularly suitable for these territories. In the German case, they relied on the potato that had originated in the South American continent and later became a vital means of sustenance all over the European continent. As for the Italians, they found their forte in a traditionally Mediterranean practice such as wine production thanks to a North American variety, particularly suitable in the harsh environment of the Brazilian uplands. The result of this co-evolutionary adaptation journey was the syncretic biocultural experience that still characterises this distinctive region of the world today.

\section{Acknowledgements}

This article is the result of a collaboration initiated during the third World Congress of Environmental History (Florianopolis, 2019). We would like to thank some of the researchers who shared their expertise with us during the congress, stimulating and encouraging us in the creation of this article. Among them we particularly thank João Klug, Eunice and Rubens Nodari, Claiton Marcio da Silva, Roberta Biasillo, Daniele Valisena, Marco Armiero, Mark Hersey, Samira Moretto, Jo Klanovicz, José Augusto Pádua, Georg Fischer, Marcos Gerhardt, Manoel Pereira dos Santos and Frederik Schulze. Special thanks goes to Vitória Fank Spohr for helping with the map used here. We also thank IREH editor James Beattie, whose assistance was essential for the completion of this article in its current version, and the two anonymous reviewers who revised the text, sharing their expertise with constructive criticism. The research was financed by the Andrea von Braun Foundation, The German Academic Exchange Service (DAAD), the Coordination for the Improvement of Higher Education Personnel (CAPES) and the Rachel Carson Center for Environment and Society. 
This text is taken from International Review of Environmental History, Volume 6, Issue 1, 2020, edited by James Beattie, published 2020 by ANU Press, The Australian National University, Canberra, Australia.

doi.org/10.22459/IREH.06.01.2020.01 